\title{
A Perspective-Based Reading of Culture in English Language Teaching: From the Conventional Perspective to the Intercultural Language Teaching Perspective
}

\author{
Khaled Jebahi ${ }^{1,2}$ \\ ${ }^{1}$ Higher Institute of Human Sciences of Medenine, University of Gabes, Gabes, Tunisia \\ ${ }^{2}$ Northern Border University, Arar, KSA \\ Email: khaldfr@yahoo.fr
}

Received March $8^{\text {th }}, 2013$; revised April 11 $1^{\text {th }}, 2013$; accepted April $20^{\text {th }}, 2013$

\begin{abstract}
Copyright $(C) 2013$ Khaled Jebahi. This is an open access article distributed under the Creative Commons Attribution License, which permits unrestricted use, distribution, and reproduction in any medium, provided the original work is properly cited.
\end{abstract}

\begin{abstract}
This paper reviews culture as perceived in a number of language teaching perspectives. The term "culture" and its relation with language has been a center of interest in different fields of studies. Because the term "culture" is borrowed between disciplines, it is understood differently and altered in the process by the goals and traditions of the borrowers. As such culture remains an elusive concept for the language teacher. Here, I attempt to understand how culture has been understood in different English language teaching perspectives in the last fifty years. This reading helps understand how change in the teaching approach affects how culture is dealt with in class and in teaching materials.
\end{abstract}

Keywords: Culture; Perspective; Language Teaching; Language Learning; English

\section{Introduction}

This review article is an attempt to survey culture as perceived in a number of language teaching perspectives. There are as many definitions of the term "culture" as there are fields of studies. This term has been understood differently by linguists, anthropologists, sociologists, psychologists, etc. Each field of study understood the term with reference to its goals and traditions. As such, the concept of culture remains elusive to the language teacher.

The reader's attention is drawn to the fact that this study is based on the work of Williams (2005) who was, to the best of my knowledge, the first to delineate a perspective-based reading of culture. My contribution is to detail some aspects which Williams did not seem to dwell on, to provide the busy language teacher with a more simplified reading of these aspects, and also to provide students with a clearer analytical view of key concepts of the issues in focus and a clearer understanding of the perspectives in question.

This article provides a comprehensive, if brief, overview of culture as reflected in a number of perspectives. Focus is only on the main trends within each perspective.

\section{The Conventional Perspective}

Anthropology, being one of the behavioural sciences, formed the basis of understanding of culture in the conventional perspective. Anthropology is derived from the Greek anthropos meaning "man" as a gender-neutral term (that is including females) and logia meaning "the study of". Anthropology, then, is the study of aspects of human beings like their origin, past, present, and future. From the perspective of linguistic anthro- pology, culture is heavily drawn upon in the second language teaching literature (Brody, 2003).

In the conventional perspective, culture is explored both explicitly and implicitly.

\section{Culture Explicitly Explored}

This relates to the behaviourist understanding of language teaching and learning.

Behaviorism, essentially a psychological theory, is a theory of learning based on the premise that all behaviour is acquired through conditioning. All learning, including language learning, is considered an acquisition of a new behavior, and learning is developing responses to environmental stimuli. If responses receive positive reinforcement, they become habits. If they receive punishments, the learner, particularly the child acquiring their mother tongue, will abandon them, and so on and so forth. Learning then is a habit formation process.

In Robert Lado's foreword to Linguistics across cultures (1957), Charles Fries wrote the following:

"Before any of the questions of how to teach a foreign language must come the much more important preliminary work of finding the special problems arising out of any effort to develop a new set of language habits against a background of different native language habits".

Lado's approach (the Contrastive Analysis Hypothesis or $\mathrm{CAH}$ for short) was to "predict and describe the pattern that will cause difficulty in (L2) learning, and those that will not cause difficulty, by comparing systematically the language and culture to be learned with the native language and culture of the student" (Lado, 1957: vii). This can be achieved using the in- 
formant approach along with a systematic observation of the culture "in its normal undisturbed operation" (Lado, 1986: p. 61). In a similar fashion, Brooks (1986) presented a lengthy list of topics that teachers may consider as "hors d'oeuvres" items in the language classroom. This list includes topics that can bring out identity, similarities, or differences in comparable patterns of cultures.

In the late 1960s and 1970s, however, the behaviourist operant conditioning tenets were found to be no longer tenable. Chomsky's $(1959,1965)$ critique of behaviorism were by then predominant in the field of linguistics. In his mentalist-rationalist theories, children were thought to bring an innate facility to guide their learning of language. This innate facility was unaffected by the kinds of conditioning forming the basis of behaviorism. Culture is then seen as a mental competence within the individual.

In this perspective, culture is also perceived as a deep phenomenon which bears on the psychology of the individual (Paulston, 1978). The language learner engages in a learning process based on three levels: cognition, affection, and action. First, the learner cognitively tries to analyze what and why about other cultures. The learner uses his or her conscious mental process to understand cultural aspects such as family system, education, religion, etc. and to somehow acquire an ability to view the outside world as the people of that culture view it. Second, the learner may perceive and appreciate aspects of another culture. $\mathrm{S} /$ he then engages in a process of revaluating values which may lead to a reorientation and a change of her/his life before he or she finally becomes one of them, viz of the people of the second culture. Third, comes action which Paulston left undeveloped; we can guess, however, that this level involves either embracing or rejecting values of the host culture. For Paulston (1978) becoming bilingual is perfectly possible, but becoming bicultural heavily depends on a multitude of affective factors.

In the 1980s, Valdes (1986) and Damen (1987) relied on anthropology to understand culture. They were dissatisfied with learning materials, with the cultural concepts and values to be stressed in class and which remained unclear to teachers, and also with classroom learning which, in their views, remained memorization-based.

In the 1990 s, conventional literature on language teaching became more influenced by relatively new understandings of culture. The British theorist Raymond Williams's conception of culture as "ordinary, in every society and every mind" (Williams, 1989: p. 4) and Jurgen Habermas' theory of communicative action (Habermas, 1984) started to be reflected in the literature of the time. Habermas's theory of communicative action is basically a challenge to the Marxist view which considers economics as a factor of oppression. To Habermas, language and communication between people are essential to liberation.

Williams and Habermas, among others (such as Bourdieu and his theory of social practice), theorized the interplay between culture, ideas, and everyday life. Habermas (1984), for instance, theorizes communicative interaction, also called language as practice as a "process implicitly guided by regulative norms of respect and reasonableness" (Young, 2002: p. 38). In Habermas' view, humans are certainly horribly selfish and willing to do the most atrocious things. The role of everyday communication, however, is to minimize conflict and to help people understand one another's meanings and intentions.

Habermas was criticized for espousing a too utopian theory
(Savage, 2000) and for treating social movements as unified entities and for not differentiating the variety of factors at work between such movements (Melucci, 1989).

\section{Culture Implicitly Explored}

Culture is a basic tenet in the fabric of the communicative approach. Knowledge about cultural aspects and contexts seems necessary for a proper use of communicative skills (Duquette, 1995). However, culture has been marginalized (Corbet, 2003) and made invisible (Philips, 1983) in communicative curricula.

One main reason behind marginalizing culture is the distortion of the concept of "communicative competence" especially by material designers and practitioners.

Unfortunately many theorists and teachers have come to equate the concept of communicative competence with spontaneous self-expression, probably because they have taken the term absolutely literally as the ability to communicate. This interpretation is not only trite but also shows a grave lack of understanding of what is involved. Loveday (1981: p. 61).

This emphasis on the "ability to communicate" and on how to do things with language "had overshadowed its [i.e. the communicative competence's] cultural aspects" (Corbett, 2003: p. 21). This also seems influenced by the development of what is called the notional-functional approach. In the early 1970s, Europe's significant economic, political, and infrastructural integration led to linguistic consequences. The Modern Languages Project was sponsored by the Council of Europe to develop new syllabi that can meet learners' needs in a context where monolingualism became a hurdle in the face of those abovementioned changes.

So, despite the fact that culture is a basic component of communicative competence, the focus on the transactional level of communication resulted in marginalizing culture or aspects of culture which needed to be more present in communicative curricula.

Put simply, culture is omnipresent in the theoretical literature on communicative language teaching but it remained practically implicit and "hidden" (Byram, 1989: p. 1) in the second and foreign language materials which focused on the transactional level of language. Corbett (2003: p. 24) maintains that even researchers who are aware of the practical neglect of culture do not seem to provide ways of integrating it in communicative language teaching classrooms. This, among other factors discussed in the section below, led to the extension of the conventional perspective.

\section{The Conventional Perspective Extended}

Literature in the extended model of the conventional perspective generally tends to influence classroom practice with regard to cultural content. Wurzel and Fishman (1995) came with the concept of cultural community within US schools. Cultural community is defined as one community in which meaningful communication between all its group members is fostered (Coffey, 1999). In the US schools, where the foundations of Wurzel and Fishman's work are laid, community groups do not have a common worldview encompassing shared knowledge, beliefs, values, attitudes, communication styles, and history. Teachers are expected to build a sense of cultural community in the classroom. This requires two basic steps: preparing students (some might show resistance) to cooperate and par- 
ticipate in an interactional process and preparing teachers themselves who may need more time as some of them lack the ability to integrate those different life experiences, historical, and cultural backgrounds of their learners into their courses. To help teachers build cultural community in their classes, Coffey (1999) provides guidelines regarding curriculum content, activities, and classroom climate. For instance, regarding curriculum content, Coffey (1999: p. 29) recommends selecting topics and materials that help students to debate key concepts, to think critically about issues, to give reactions to and opinions about key issues, etc. Although different techniques are proposed by researchers, they all involve an explicit cross-cultural exploration of cultural experiences of learners belonging to different cultural backgrounds. As such the cultural perspectives of participants in cultural events or experiences are explored and studied from different angles.

This part of the literature, however, continued to work without explicitly acknowledging other perspectives. This led to the revision of the conventional perspective.

\section{The Conventional Perspective Revised}

In the revisionist literature, an attempt is made to reconcile a conventional understanding of culture with ideas espoused by other perspectives. This part of the literature also addresses issues and problems arising within the conventional perspective.

Postmodern perspectives, for instance, challenge the received view of culture. To Atkinson (1999), what seems to be questioned is the conventional view of cultures as distinct, relatively unchanged, homogeneous, and all-encompassing norms determining personal behaviour. Terms like Japanese culture, Hispanic culture, and American culture are just examples of this "received" view on cultures now problematized by postmodernists. Now cultures are regarded as anything but homogeneous and monolithic entities.

Ignold (1994: 330) maintains that

The idea that humanity as a whole can be parcelled up into a multitude of discrete cultural capsules, each the potential object of disinterested anthropological scrutiny, has been laid to rest at the same time as we have come to recognize the fact of interconnectedness of the world's peoples, not just in the area of modern transport and communications, but throughout history. The isolated culture has been revealed as a figment of the Western anthropological imagination. It might be more realistic, then, to say that people live culturally rather than they live in cultures.

To reconcile between such challenges and the conventional perspective, Atkinson (1999) espouses a revised view of culture. The concept of culture is, then, revised and updated and a new balance is found between the emphasis on cultural stability and homogeneity on the one hand and the postmodernist critical emphasis on power, heterogeneity, fragmentation and difference. Atkinson postulated six principles to reconcile the two contrasting views:

1) All humans are individuals: in the conventional views, humans/individuals are reduced to their cultural types. But now they are viewed as individuals, not as members of a cultural group. There is a new focus on individuality and personal agency as neural networks and schemas are based on personal experience and are sensitive to new input from environment.

2) Individuality is also cultural: What is regarded as one's personal makeup may also be rooted in particular cultures. In- dividuals are part of their social world.

3) Social group membership and identity are multiple, contradictory, and dynamic: Humans have multiple social roles, multiple social allegiances and live in multiple social and ever changing worlds.

4) Social group membership is consequential: membership to a social group is a result of suggestion, socialization, and enculturation.

5) Methods of studying cultural knowledge and behaviour are unlikely to fit a positivist paradigm: ethnographic and qualitative approaches, though underused and underappreciated, can be useful in action research, curriculum design, programme evaluation projects, etc.

6) Language (learning and teaching) and culture are mutually implicated, but culture is multiple and complex: knowledge of language and how to use it are inextricably intertwined with a knowledge of culture which is always multiple and complex.

The revisionist literature also dwells on problems arising from within the conventional perspective. These include issues relating to non-native teachers of English. The communicative approach with its standardized view to the native speaker as a crucial element in teaching models is now found "utopian [and] unrealistic" (Alptekin, 2002: p. 57).

\section{The Systemic Functional Linguistics Perspective}

This model has co-existed with the conventional framework for several decades. Systemic functional linguistics (SFL) (also referred to as genre theory) is one of the seminal traditions in linguistic research and one school of thought based on the linguistic theory of the British linguist Michael Halliday. Christie and Unsworth (2000) state that the distinctiveness of the theory is due to its comprehensive scope in that it attempts to answer questions about language in applied contexts, namely the educational (how to best teach and learn a language), the computational (how to model language for automatic text generation), sociological (the role of conversation in creating the self and society), and the literary (how a text means what it does and comes to be valued as it is).

Halliday's systemic functional linguistics argues that all languages are described in terms of networks of choices of meaning. A set of choices may include "singular/plural number, past/ present/future tense, positive/negative polarity" Christie and Unsworth (2000: p. 2). This set is called system, hence the name systemic. As to the label "functional", the argument made by Halliday (1978: p. 52) is that all languages or linguistic systems evolve around three major functions: 1) the ideational (how to present experiences, to express content, and to convey information); 2) the interpersonal (how to interact verbally in order to establish and maintain social interaction); and 3) the textual (how to use language to create coherent and connected messages/discourse). Hence, in using language, speakers make choices within the various linguistic systems and make meaning using the ideational, interpersonal, and textual functions present in all languages.

However, this approach has been critiqued for its emphasis on genre as a linguistic form rather than on the cultural dimensions of texts (Corbett, 2003). As an approach, SFL is portrayed as too linguistic and too structural with little account of social theory. According to Poynton (1993), this can lead us to believe in the singularity of the text. Thus singular readings become the norm and cultural expectations and practices tend to be pre- 
sented as homogeneous, fixed, and consistent.

\section{The Practical Perspective}

Three main frameworks form the basis of the practical perspective on teaching culture within language teaching in general. The label "practical" is used here because these frameworks present clear ideas which can be put into practice and steps which can guide teachers' work.

To begin with, Fantini (1997: pp. 40-42) presented what he called a "process approach framework" consisting of a sevenstep guideline for developing intercultural competence. This framework was devised to ensure that "language work is always complemented by explicit attention to sociolinguistic aspects, cultural aspects, and the comparing and contrasting of target and native linguacultures" (p. 41).

Fantini's "process approach framework" was also described as a mechanization process which seems to be at the origin of routinized processes, mechanized answers, and stereotyped ways of explaining cultures and cross-cultural encounters. There are unexpected moments in a class when the teacher would find ready-made recipes of little use (Manjarrés, 2009: p. 148). It was also found that such mechanistic processes and ready-made recipes originated simplistic images of the target cultures and even led to an idealization of the cultures of economically developed countries (Boehringer \& Preece, 2002; Boehringer, Gongartz, \& Gramberg, 2004).

The second framework was put up by Canagarajah (1999). It is a systematic exploration of culture based on a critical approach or perspective to pedagogy. In a context where the English language has been spreading globally, Canagarajah presents this framework which espouses the idea that inner circle pedagogies are inappropriate in outer circle contexts. This framework is an attempt to help outer circle students and teachers to challenge and question the teaching beliefs and practices of the "center" which Canagarajah refers to as "the technologically advanced communities of the West which, at least in part, sustain their material dominance by keeping less developed communities in periphery status" (p. 4).

The main purpose of Canagarajah's "critical pedagogy" is to "transform the means and ends of learning and to construct a more egalitarian, equitable, and ethical educational and social environments untainted by power and domination" (Hinkel, 2005: 839). Canagarajah argues for a deconstruction of texts which can lead teachers and students to ask questions not only about the text and its author but also about proper conversational styles of the center communities found in the text and how such styles differ from those of the students.

The third systematic framework is based on Conversation Analysis (CA). Conversation Analysis is defined as the "systematic analysis of the talk produced in everyday situations of human interaction" (Hutchby \& Wooffitt, 1998: p. 13). Although the field adopted the name "conversation analysis", Hutchby and Wooffitt (1998) prefer the term "talk-in-interaction" to the term "conversation" because the range of forms subject to study within CA is far larger than the term conversation alone would imply. CA practitioners analyse mainly transcribed tape-recordings of actual interactions situated in the ordinary lives of people rather than of those arranged and set up in laboratories. CA is, then, the study of recorded, naturally occurring talk-in interaction to "uncover the tacit reasoning procedures and sociolinguistic competencies underlying the production and interpre- tation of talk in organized sequences of interaction" (Hutchby and Wooffitt (1998: 14). Barraja-Rohan (2000) and BarrajaRohan and Pritchard (1997) devised an innovative methodology based on Conversation Analysis and elements of Politeness Pragmatics to teach oral communication skills. This methodology involves the following consecutive phases:

- An awareness phase: a model of an everyday conversation is presented on audio or videotape

- A reflective phase: the model's structures and features are analysed by the learners

- An experimental phase: relevant language is implemented by learners in role plays

- An introspective phase: learners reflect on their feelings when acting in ways different from their own

- A cultural evaluation phase: an explicit comparison between what happens in English and what might happen in similar contexts in conversations in the learners' first language

\section{The Critical and Post-Structuralist/Post-Modernist Perspective}

In English language teaching, there exist two bodies of schoolarly literature which can be ascribed the term "critical". The first body of literature is called "Critical Applied Linguistics", which argues that there has been favouritism in teaching English across the globe towards inner circle pedagogies, teachers, and materials, and this implicitly means that there is favouritism of the inner circle culture. The second body of literature is more theoretically oriented in that it seeks to apply poststructuralist/postmodernist understandings to aspects of English language teaching, in particular cultural teaching and learning.

\section{Critical Applied Linguistics}

This part of literature basically argues that English language teaching (ELT) practices in the outer and expanding circles are the product of an inner circle profit making industry within an unequal capitalist world economy. Inner circle pedagogies tend to mould learners from the outer and expanding circle backgrounds to meet cultural and rhetorical practices of the inner circle. This, consequently, creates a stereotypical view of learners and their culture as inferior. In congruence with this, Holliday (2011) calls for a revision of the way we think of intercultural communication in order to consider its ideological component because ideology is influential in intercultural communication traditional schools. Holliday attempts to emphasis the need for a new cosmopolitan viewpoint beyond the centre picture, a new viewpoint in which non-western cultural realities are no longer marginalized.

Some Other critiques were directed at the cultural orientation of certain competency-based teaching programmes targeting adult immigrants in the United States. According to Auerbach (1986), any refugee who wished to receive federal assistance had to enrol in such competency-based programmes. Such programmes are defined as "a performance-based process[es] leading to demonstrated mastery of basic life skills necessary for the individual to function proficiently in society" (Parker \& Taylor, 1980: pp. 12-13). These programmes, however, seemed to have offered limited options for immigrant learners who were only socialized "for specific roles in the existing socioeconomic order" (Auerbach, 1986: p. 411). 


\section{Post-Structuralist/Post-Modernist Perspective}

In this part of the literature, postmodernism/poststructuralism of Pierre Bourdieu and Michel Foucault is drawn upon. Both distinguish between "the objective truth of the world" and the subjective "lived truth of what we are" (Bourdieu \& Wacquant, 1992: p. 225). There exist discursive processes in the formulation of "double truth" making up objectivism and subjectivism, two different ways of knowing the social world. The subjective, or this invisible world going on in the head of people and the objective, or this outside social world, the world of social structure and unifying patterns are what makes this double truth. These distinctions are even found in the nature of culture with its "received" variant called into question as it is constructed by hegemonic groups serving the interests of dominant classes and marginalizing other groups. These dominant classes' concept of identity, according to Weber and Horner (2012), is essentialist in that they expect speakers of minority languages to assimilate to the core of the mainstream culture. Culture is, then, a social phenomenon linked to power struggle between individuals with different affiliations to different social groups.

\section{The Sociocultural Perspective}

A relatively recent development in the teaching of English language and culture has been the introduction of the sociocultural theory, originally conceived by Lev Vygotsky whose ideas turned out to be very instrumental in framing learning processes and practices in Russia, Europe and the United States of America (Kozulin, 2003). Vygotsky's (1978) theory is based on the premise that human cognition and learning are social and cultural rather than individual phenomena.

Intellectual development is understood in terms of intellectual or symbolic tools such as language accumulated as we grow up in a society. Language forms appropriated in the mind coexist together. Likewise, new forms of understandings do not displace precedent ones but coexist complementarily. Vygotsky believes that learning and development are both closely socioculturally related. A child's development, for instance, is dependent on an interaction between the child's individual maturation and a system of symbolic tools (language is one of them) and the activities the child appropriates from the sociocultural environment.

One such example is the activity of pointing a finger. At first, this activity starts as a meaningless grasping motion. With the passing of time, others start reacting to the gesture which then acquires a meaning (Vygotsky, 1978). This is an example of how learning is seen as moving from an external social plane to an internal psychological plane (Lantolf, 1999).

\section{The Intercultural Language Teaching Perspective}

The original ideas at the basis of this perspective can be traced back to works of Byram (1989), Buttjes and Byram (1991), Byram and Morgan (1994), and Byram (1997) which originally related to language teaching in Europe. Byram (1989) wrote about the critical need of further research on the assessment of the cultural dimension as he was invited to participate in the Council of Europe's project to develop a "Common European Framework of Reference for Language Learning and Teaching", a framework based on levels of proficiency in the use of languages. Byram's task, in collaboration with Geneviève Zarate, was to clarify issues involved in determining levels of sociocultural competence.

Intercultural language teaching (ILT) is to be understood "as an approach to language teaching which argues that communicative language teaching and its conceptualisation of culture has not been sufficiently systematic or adequate" (Williams, 2005: p. 113). Put differently, intercultural language teaching is a rethinking of communicative language teaching. ILT alleges that communicative language teaching fell short of systematically incorporating culture and language teaching (Crozet and Liddicoat, 1999). This, however, does not entail a rejection of communicative language teaching; in fact, Byram and Morgan (1994) and Byram (1997) used the concept "intercultural communicative competence", a concept which obviously highlights the connection between communicative competence and intercultural competence. In addition, ILT builds on communicative language teaching and takes into consideration the needs of intercultural speakers, speakers whose needs are different from native speakers' communicative needs; and hence require a different kind of competence.

This change in approach, as mentioned earlier, can affect how culture is dealt with in class and in the teaching materials. In ILT, for instance, focus is on "intercultural speakers" whose needs differ from those of native speakers. So, teachers and material designers who are aware of the changes affecting societies and the global job market may ponder upon the kinds of linguistic-cum-cultural skills that might be needed by the intercultural speakers who work in a culture different from their own. Teachers and material designers who are aware of such changes in approach can gear teaching materials and teaching and learning practices towards those new needs of intercultural speakers. Teaching materials and classroom practices can focus on cultural features such as norms of politeness, appropriate intonation patterns, conventions of interpersonal relationships and social interactions, and main rhetorical conventions in different written and spoken genres, all these are needed by intercultural speakers who work or study in a culture different from their own. Hence, how culture is dealt with in class and in the teaching materials depends on a clear understanding of the teaching approaches which are linked to the needs of particular learners in particular contexts.

\section{Conclusion}

This paper is a review of culture as defined in a number of perspectives from the 1950 s on. Motivated by lack of a clear understanding of the term culture, mainly because of its being borrowed between the disciplines, this study aims at providing an articulate, cogent, and simplified reading of it. Differences and similarities between language teaching and learning perspectives are studied in such a way as to provide a clear and thorough understanding of the concept of culture and a clear analysis of other related key concepts in language teaching such as anthropology, postmodernism, critical applied linguistics, sociocultural theory, etc. It is found that the understanding of the concept of culture in these perspectives influences teaching and learning practices. There are educational implications for the change in views about culture in the perspectives in question. One example could be taken from the mechanical habit formation learning process in the conventional perspective whose first theoretical foundations lie in behaviourism. In this perspective, for instance, students memorize and learn the different 
cultural behaviours found across the globe through repetition and habit formation. Later, with the introduction of the mentalist-rationalist theories in the conventional perspective, memorization and drills are replaced with a reflective conscious process guided by an innate facility which is unaffected by the kinds of conditioning forming the basis of behaviourism. Learners, in mentalist-rationalist theories, analyze cultural patterns, test them against prior knowledge, and then either accept or reject them. As argued in the main body of this paper, changes in the understanding of the concept of culture in the remaining perspectives continued to influence teaching and learning practices. This paper can help teachers, students, material designers, and researchers have a clearer understanding of culture in the different English language teaching and learning perspectives. It can also help them better understand teaching and learning practices and better identify the theoretical foundations of the materials used in class.

\section{Acknowledgements}

I would like to thank the Research Center for English and Applied Linguistics at the University of Cambridge, UK, which was a source of inspiration during the early stages of conducting this work which is part of a larger $\mathrm{PhD}$ research.

\section{REFERENCES}

Alptekin, C. (2002). Towards intercultural communicative competence in ELT. ELT Journal, 56, 57-64. doi:10.1093/elt/56.1.57

Atkinson, D. (1999). TESOL and culture. TESOL Quarterly, 33, 625654. doi: $10.2307 / 3587880$

Auerbach, E. (1986). Competency-based ESL: One step forward or two steps back? TESOL Quarterly, 20, 411-429. doi:10.2307/3586292

Barraja-Rohan, A. (2000). Teaching conversation and sociocultural norms with conversation analysis. In A. J. Liddicoat, \& C. Crozet (Eds.), Teaching language, teaching culture. Australian review of applied linguistics (pp. 71-88).

Barraja-Rohan, A., \& Pritchard, R. (1997). Beyond talk: A course in communication for intermediate learners of English as a second language. Melbourne: Western Metropolitan Institute of TAFE.

Boehringer, M., \& Preece, S. (2002). Culture for dummies: Evaluating for the impact of international business primers. Journal of Language for International Business, 11, 11-21.

Boehringer, M., Gongartz, C., \& Gramberg, A. K. (2004). Language learning and intercultural training: The impact of cultural primers on learners and nonlearners of German. The Journal of Language for International Business, 15, 1-18.

Bourdieu, P., \& L. Wacquant. 1992. An invitation to reflexive sociology. Chicago: University of Chicago Press.

Brody, J. (2003). A linguistic anthropological perspective on language and culture in the second language curriculum In D. Lange, \& R. M. Page (Eds.), Culture as the core: Perspectives on culture in second language education (pp. 37-52). Greenwich Information Age Publishing INC.

Brooks, N. (1986). Culture in the classroom. In J. M. Valdes (Ed.), Culture bund (pp. 123-129). Cambridge: Cambridge University Press.

Buttjes, B., \& Byram, M. (1991). Mediating languages and cultures: Towards an intercultural theory of foreign language education. Clevedon: Multilingual Matters.

Byram, M. (1989). Cultural studies in foreign language education. Clevedon: Multilingual Matters Ltd.

Byram, M., \& Morgan, C. (1994) Teaching-and-Learning languageand culture. Clevedon: Multilingual Matters.

Byram, M. (1997). Teaching and assessing intercultural communicative competence. Clevedon: Multilingual Matters.

Canagarajah, A. (1999). Resisting linguistic imperialism in English language teaching. Oxford: Oxford University Press.
Chomsky, N. (1959). A review of B. F. Skinner's verbal behavior. Language, 35, 26-57. doi:10.2307/411334

Chomsky, N. (1965). Aspects of the theory of syntax. Cambridge, MA: The MIT Press.

Christie, F., \& Unsworth, L. (2000). Developing socially responsible language research. In L. Unsworth (Ed.), Researching language in schools and communities: Functional linguistic perspectives (pp. 126). London: Cassell.

Coffey, M. (1999). Building cultural community in English language programs. TESOL Journal, 8, 26-30.

Corbett, J. (2003). An intercultural approach to English language teaching. Clevedon: Multilingual Matters Ltd.

Crozet, C., \& Liddicoat, A. (1999). The challenge of intercultural teaching: Engaging with culture in the classroom. In J. Lo Bianco, A. Liddicoat, \& C. Crozet (Eds.), Striving for the third place: Intercultural competence through language education (pp. 113-123). Melbourne: Language Australia.

Damen, L. (1987). Culture learning: the fifth dimension in the language classroom. Cambridge: Cambridge University Press.

Duquette, G. (1995). Second language practice: Classroom strategies for developing communicative competence. Clevedon: Multilingual Matters Ltd.

Fantini, A. (1997). New ways in teaching culture. Alexandria, VA: TESOL Inc.

Habermas, J. (1984). The theory of communicative action. Boston, MA: Beacon Press.

Halliday, M. (1978). Language as social semiotic: The social interpretation of language and meaning. London: Edward Arnold.

Hinkel, E. (2005). Handbook of research in second language teaching and learning. Mahwah, NJ: Lawrence Erlbaum Associates.

Holliday, A. (2011). Intercultural communication and ideology. London: Sage.

Hutchby, I., \& Wooffitt, R. (1998). Conversation analysis: Principles, practices, and applications. Cambridge: Polity Press.

Inglod, T. (1994). Introduction to culture. In T. Ingold (Ed.), Companion encyclopedia of anthropology: Humanity, culture, and social life (pp. 329-349). Routledge: London.

Kozulin, A. (2003). Vygotsky's educational theory in cultural context. Cambridge: Cambridge University Press. doi:10.1017/CBO9780511840975

Lado, R. (1957). Linguistics across cultures. Ann Arbor: The University of Michigan Press.

Lado, R. (1986). How to compare two cultures. In J. M. Valdes (Ed.), Culture Bound (pp. 52-63). Cambridge: Cambridge University Press.

Manjarrés, N. (2009). Intercultural competence: Another challenge. PROFILE: Issues in Teachers' Professional Development, 11, 143158.

Lantolf, J. (1999). Second culture acquisition. In Hinkel, E. (Ed.), Culture in second language teaching and learning (pp. 28-46). Cambridge: Cambridge University Press.

Loveday, L. (1981). The sociolinguistics of learning and using a nonnative language. Oxford: Pergamon.

Melucci, A. (1989). Nomads of the present: Social movements and individual needs in contemporary society. Philadelphia: Temple University Press.

Parker, J., \& Taylor, P. (1980). The CB reader: A guide to understanding the competency-based adult education movement. Upper Montclair, NJ: National Adult Education Clearinghouse, Center of Adult Continuing Education, Montclair State College.

Paulston, C. (1978). Biculturalism: Some reflections and speculations. TESOL Quarterly, 12, 369-380. doi:10.2307/3586136

Philips, S. U. (1983). The invisible culture: Communication in classroom and community on the warm springs Indian reservation. New York: Longman.

Poynton, C. (1993). Grammar, language and the social: Poststructuralism and systemic-functional linguistics. Social Semiotics, 3, 1-21. doi:10.1080/10350339309384407

Savage, M. (2000). Class analysis and social transformation. Milton Keynes: Open University.

Valdes, J. (1986). Culture bound: Bridging the cultural gap in language teaching. Cambridge: Cambridge University Press. 


\section{K. JEBAHI}

Vygotsky, L. S. (1978). Mind in society: The development of higher psychological processes. Cambridge, MA: Harvard University Press.

Weber, J., \& Horner, K. (2012). Introducing multilingualism: A social approach. London: Routledge.

Williams, R. (1989). Resources of hope: Culture, democracy, socialism. London: Verso.

Willams, A. (2005). Resolving the culture conundrum: A conceptual framework for the management of culture in TESOL. Unpublished
PhD Thesis, Latrobe: Latrobe University.

Wurzel, J. S., \& Fischman, N. K. (1995). A different place: The intercultural classroom. [Two-part training video and instructional guide] Newtonvile, MA: Intercultural Resource Corporation.

Young, I. (2002). Inclusion and democracy. Oxford: Oxford University Press. doi:10.1093/0198297556.001.0001 